\title{
MEMBANGUN PRODUK PERATURAN DAERAH PERTAMBANGAN MINERAL DAN BATUBARA BERBASIS CITA HUKUM PANCASILA
}

\author{
Andi Sugirman \\ Sekolah Tinggi Agama Islam Negeri Watampone, Bone, Indonesia \\ e-mail: andisugirman@gmail.com
}

\begin{abstract}
Building the legal product of a regional regulation on mineral and coal mining is the authority of regional governments. In implementing their authority, they are required to apply Pancasila and embrace the 1945 Constitution of the Republic of Indonesia. Pancasila consisting of five precepts is a legal ideal that should be incarnated in the legal product of a regional regulation on mineral and coal mining. The incarnation of the legal ideal of Pancasila through the legal product of a regional regulation on mineral and coal mining will have the implication on mineral and coal mining management based on the legal ideal of Pancasila. Therefore, building the regional regulation on mineral and coal mining must be based on the normative-juridical aspect as the basis for the making of laws and the theoretical aspect based on the legal ideal of Pancasila.
\end{abstract}

Keywords: Pancasila, Mining, Regional Regulation

\section{Pendahuluan}

Lahirnya negara dan bangsa Indonesia para pendiri negara telah pula menyepakati Pancasila dan UUD 1945 sebagai dasar dan konstitusi negara. ${ }^{1}$ Pancasila sebagai dasar negara yang jiwa dan esensinya dirumuskan dalam Pembukaan beserta seluruh substansi Undang-Undang Dasar 1945. Menjadi dasar yang memberikan tuntunan bagaimana penyelenggaraan negara dilaksanakan, dan arahan bagaimana tujuan negara serta tugas-tugas pemerintahan negara harus di capai. ${ }^{2}$

Soehino menyatakan bahwa, Negara Kesatuan Republik Indonesia berdasarkan Pancasila dan UUD 1945 adalah Negara Hukum, yaitu negara yang segala aktivitasnya baik yang dilakukan oleh penguasa maupun oleh warga negara

\footnotetext{
1 Dahlan Thaib, 2009, Ketetanegaraan Indonesia Perspektif Konstitusional, Yogyakarta:Total Media, hlm. 14.

2 Bambang Kesowo, 2007, Aktualisasi Kultur Hukum Dalam Sistem Hukum Pancasila, Makalah, Disajikan Dalam Seminar Nasional, Universitas Gadja Mada, Yogyakarta: Fakultas Hukum dan KAGAMA, hlm. 3.
} 
harus berdasarkan atas ketentuan-ketentuan hukum dan atau aturan-aturan hukum. ${ }^{3}$ Hukum harus menjadi dasar dan panduan bagi setiap penyelenggaraan pemerintahan negara. Didalam praktik penyelenggaraan pemerintahan negara dilakukan oleh aparat negara. ${ }^{4}$

Bernard Arief Sidharta berpendapat bahwa, negara Pancasila yang dicitacitakan adalah negara hukum yang berdasarkan asas kerakyatan bertujuan untuk mewujudkan kesejahteraan berkeadilan (keadilan sosial) bagi seluruh rakyat Indonesia serta perdamaian dunia. ${ }^{5}$ Untuk mewujudkan tujuan negara Pancasila, salah satu instrumen yang dipergunakan oleh penyelenggara negara adalah melalui perangkat peraturan perundang-undangan sebagai payung dalam memberikan legitimasi pada berbagai tindakan dan atau perbuatan penyelenggara negara, maupun tindakan dan atau perbuatan warga negara. Karena itu penyelenggara negara diberikan kewenangan untuk membuat instrumen hukum berupa peraturan perundang-undangan, baik penyelenggara negara tingkat pusat maupun penyelenggara negara pada tingkat daerah provinsi dan daerah kabupaten kota.

Berkaitan dengan kewenangan penyelenggara pemerintahan daerah dalam membuat produk hukum peraturan daerah, yang salah satu diantaranya adalah membuat produk hukum yang sangat vital dan esensial sebab menyangkut hajat hidup orang banyak yakni, di bidang pengusahaan pengelolaan sumber daya alam berupa pertambangan mineral dan batubara. Karena itu dalam rangka pengaturan dan pendistribusiannya harus dapat mendatangkan kesejahteraan dan kemakmuran bagi rakyat Indonesia, sebagaimana diamanatkan dalam Pasal 33 ayat (3) UUD NKRI 1945. Maka dengan demikian dalam tulisan ini hendak mengkaji bagaimana membangun produk hukum peraturan daerah pertambangan pertambangan mineral dan batubara berbasis cita hukum Pancasila, sehingga dalam pengusahaan pengelolaan pertambangan mineral dan batubara tidak berbasis liberal kapitalistik. Dengan demikian dalam menyusun undang-undang, pembentuk undang-undang perlu dengan tepat menunjukkan nilai-nilai Pancasila, yang mendasari ketentuan undangundang itu. Dengan demikian peraturan-peraturan hukum merupakan pelaksanaan

3 Soehino, 2006, Hukum Tata Negara Teknik Perundang-Undangan (Setelah Perubahan Pertama dan Perubahan Kedua Undang-Undang Dasar Negara Republik Indonesia Tahun 1945), Yogyakarta:BPFE, hlm.18.

${ }_{4}$ Dahlan Thaib, Op,Cit., hlm. 27.

5 Bernard Arief Sidharta, 1996, Refleksi Tentang Fundasi Dan Sifat Keilmuan Ilmu Hukum Sebagai Landasan Pengembangan Ilmu Hukum Nasional Indonesia,Disertasi, Bandung: Universitas Padjadjaran, hlm. 57-58. 
undang-undang itu tidak boleh mengandung hal-hal yang bertentangan dengan Pancasila. $^{6}$

\section{Cita Hukum Pancasila}

Arief Hidayat mengemukakan dapat dipahami bahwa, Pancasila merupakan norma dasar negara Indonesia (grundnorm) dan juga merupakan cita hukum Indonesia (rechtsidee) sebagai kerangka keyakinan (belief framework) yang bersifat normatif dan konstitutif. Bersifat normatif karena berfungsi sebagai pangkal dan prasyarat ideal yang mendasari setiap hukum positif, dan bersifat konstitutif karena mengarahkan hukum pada tujuan yang hendak dicapai. ${ }^{7}$ Moch. Mahfud MD, berpendapat bahwa, dari sudut hukum kedudukan Pancasila yang seperti itu melahirkan satu sistem hukum yang khas sebagai sistem hukum Indonesia yang umumnya disebut sebagai sistem hukum Pancasila. Sistem hukum Pancasila yang seperti itu memasang rambu-rambu dan kaidah penuntun dalam politik hukum nasional kita. Rambu yang paling umum adalah larangan bagi munculnya hukum yang bertentangan dengan nilai-nilai Pancasila. ${ }^{8}$

Pancasila sebagai cita hukum bangsa Indonesia, juga berkedudukan sebagai staatsfundamentalnorm. Abdul Ghofur Anshori, mengemukakan bahwa, Pembukaan UUD 1945 di dalamnya terkandung nilai-nilai religius, nilai hukum moral, nilai hukum kodrat dan nilai filosofis merupakan suatu sumber hukum material bagi hukum Indonesia. Pembukaan UUD 1945 menurut filsafat hukum dalam hierarki tata urutan perundang-undangan merupakan staatsfundamentalnorm, Dallam susunan yang hierarkis ini Pancasila menjamin keserasian atau tiadanya kontradiksi di antara berbagai peraturan perundang-undangan secara vertikal maupun horizontal. ${ }^{9}$

Pancasila yang merupakan cita hukum, maka nilai-nilai yang terdapat dalam Pancasila mempunyai fungsi konstitutif yang menentukan apakah tata hukum Indonesia merupakan tata hukum yang benar, dan disamping itu mempunyai fungsi regulatif yang menentukan apakah hukum positif yang berlaku di Indonesia

6 Barda Nawawi Arief, 2009, Kumpulan Hasil Seminar Nasional Ke I S/D VIII Dan Konvensi Hukum Nasional 2008, Semarang: Pustaka Magister, hlm. 30.

7 Arief Hidayat dan Airlangga Surya Nagara, 2011, Negara Hukum Pancasila Suatu Model Ideal Penyelenggaraan Negara Hukum, Makalah, Disampaikan Pada Semiloka Pendidikan Pancasila dan Konstitusi, Jakarta, hlm. 7.

8 Moch. Mahfud MD, 2010, Konstitusi dan Hukum dalam Kontroversi Isu, Jakarta:PT. Raja Grafindo Persada, hlm. 37-38.

9 Abdul Ghofur Anshori, 2008, Menggali Makna Sistem Hukum Dalam Rangka Pembangunan Ilmu Hukum dan Sistem Hukum Nasional, Orasi Ilmiah Dies NatalisKe-62, Yogyakarta: Fakultas Hukum UGM, hlm. 14-15. 
merupakan hukum yang adil atau tidak. ${ }^{10}$ Dengan demikian dapat dikatakan bahwa suatu produk hukum yang tidak sesuai dengan cita hukum Pancasila tidak akan melahirkan suatu tata hukum yang benar dan juga tidak akan melahirkan produk hukum yang adil. Cita hukum adalah pengertian atau konsep hukum menurut kita. Cita-cita hukum atau pengertian hukum kita kalau diikuti dengan seksama, bunyi penjelasan dari UUD kita sudah ditentukan oleh filsafat hukum kita yang dasarnya adalah Pancasila. Dengan begitu, apa yang disebut menurut hukum di Indonesia tidak dapat sama dengan pengertian hukum dari tata hukum lain. ${ }^{11}$

\section{Membangun Produk Hukum Peraturan Daerah Pertambangan Mineral dan Batubara Berbasis Cita Hukum Pancasila}

Peraturan daerah sebagai bagian dari peraturan perundang-undangan adalah merupakan produk hukum penyelenggara pemerintahan daerah yang dibuat oleh Pemerintah daerah bersama dengan Dewan Perwakilan Rakyat Daerah (DPRD), sesuai dengan tingkatannya. Pembentukan peraturan daerah adalah merupakan salah satu pelaksanaan tugas wewenang serta kewajiban penyelenggara pemerintahan daerah. Dalam melaksanakan tugas, wewenang serta kewajibannya penyelenggara pemerintahan daerah ditegaskan berkewajiban memegang teguh dan mengamalkan Pancasila. Kewajiban yang sama juga diberikan kepada anggota Dewan Perwakilan Rakyat Daerah (DPRD), untuk memegang teguh dan mengamalkan Pancasila dan melaksanakan UUD NKRI 1945 serta menaati ketentuan peraturan perundangundangan.

Kewajiban pokok yang melekat pada penyelenggara pemerintahan daerah secara normatif merupakan penuntun dalam melaksanakan tugas wewenang dan kewajibannya, termasuk dalam membuat dan atau membentuk produk hukum berupa peraturan daerah, karena itu dalam pembentukannya cita hukum Pancasila dan atau nilai-nilai Pancasila yang terdiri dari kelima sila dari Pancasila harus dituangkan dalam sebuah produk hukum berupa peraturan daerah.

Membangun sebuah peraturan perundang-undangan termasuk peraturan daerah secara yuridis normatif telah diatur dalam berbagai peraturan perundangundangan baik yang terkait dengan perosedur pembentukannya, materi muatan yang

10 A. Hamid S. Attamimi, dkk, 1991,Pancasila Sebagai Ideologi Dalam Berbagai Bidang Kehidupan Bermasyarakat, Berbangsa Dan Bernegara, Jakarta:BP-7 Pusat, hlm. 69.

${ }_{11}$ Satya Arinanto dan Ninuk Triyanti, 2009, Memahami Hukum Dari Konstruksi Sampai Implenetasi, ,Jakarta:PT. Raja Grafindo Persada, hlm. 98. 
harus diaturnya, maupun asas-asas yang harus termuat dalam sebuah peraturan perundang-undangan (Perda) tersebut. Namun demikian dalam membangun sebuah peraturan daerah yang merupakan salah satu bagian dari peraturan perundangundangan bukan hanya dapat dilihat dari perspektif yuridis normatif-nya saja, tetapi juga harus di lihat dari perspektif teoritik.

Dalam Perspektif Yuridis Normatif, pembentukan undang-undang oleh badan pembentuk undang-undang adalah perbuatan hukum penguasa yang berwenang, oleh karena itu tata cara pembentukan undang-undang harus melalui tata cara yang telah ditentukan oleh peraturan perundang-undangan. ${ }^{12}$ Peraturan daerah sebagai salah satu peraturan perundang-undangan dalam proses pembentukannya secara yuridis normatif diatur dalam Undang-Undang Nomor 12 Tahun 2011 tentang Pembentukan Peraturan Perundang-Undangan, yakni, dimulai tahap perencanaan, penyusunan, pembahasan, pengesahan rancangan atau penetapan, dan pengundangan, sebagaimana diatur Pasal 56 sampai dengan Pasal 62. Tahapan tersebut adalah merupakan sebuah prosedur dalam membangun peraturan daerah dan sekaligus sebagai alat uji berkenaan dengan keabsahan peraturan daerah tersebut.

Terlepas dari prosedur pembentukan peraturan daerah sebagaimana yang dikemukakan diatas, sebuah peraturan perundang-undangan (Perda) harus berpedoman kepada asas-asas pembentukan peraturan perundang-undangan, sebagaimana diatur dalam (lihat Pasal 5 Undang-Undang Nomor 12 Tahun 2011 tentang Pembentukan Peraturan Perundang-Undangan). Keseluruhan asas tersebut adalah merupakan cita hukum Pancasila.

Maka dengan demikian sebuah produk hukum utamanya produk hukum peraturan daerah berupa pertambangan mineral dan batubara harus mencerminkan asas-asas tersebut, dalam arti bahwa peraturan daerah di bidang pertambangan mineral dan batubara yang pengelolaannya dilakukan oleh badan usaha maupun perseorangan harus dapat mengayomi masyarakat utamanya masyarakat setempat dan mampu memberikan rasa keadilan serta manfaat yang sebesar-besarnya untuk kesejahteraan dan kemakmuran rakyat.

Dalam perspektif teoritik membangun sebuah produk hukum peraturan perundang-undangan, termasuk produk hukum pemerintahan daerah berupa peraturan daerah, harus didasarkan pada Pancasila dan Undang-Undang Dasar NKRI 1945. Oleh Khudzaifah Dimyati dikatakan bahwa, pembangunan dan pembinaan hukum di Indonesia didasarkan atas Pancasila dan Undang-Undang Dasar 1945. Paradigma yang dapat ditangkap dari Undang-Undang Dasar 1945 antara lain: $a$. Ketuhanan

12 Soehino, Lot. Cit. 
Yang Maha Esa; $b$. Kemanusiaan; $c$. Persatuan; $d$. Kerakyatan; $e$. Keadilan sosial; $f$. Kekeluargaan; $g$. Harmoni; $h$. Musyawarah. ${ }^{13}$

Sebagai paradigma pembangunan hukum, Pancasila memiliki sekurangkurangnya empat kaidah penuntun yang harus dijadikan pedoman dalam pembentukan dan penegakan hukum di Indonesia. Pertama, hukum harus melindungi segenap bangsa dan menjamin keutuhan bangsa dan karenanya tidak diperbolehkan ada hukum-hukum yang menanam benih disintegrasi. Kedua, hukum harus mampu menjamin keadilan sosial dengan memberikan proteksi khusus bagi golongan lemah agar tidak tereksploitasi dalam persaingan bebas melawan golongan yang kuat. Ketiga, hukum harus dibangun secara demokratis sekaligus membangun demokrasi sejalan dengan demokrasi (negara hukum). Keempat, hukum tidak boleh diskriminatif berdasarkan ikatan primordial apa pun dan harus mendorong terciptanya toleransi beragama berdasarkan kemanusiaan dan keberadaban. ${ }^{14}$

Sejalan dengan uraian tersebut di atas Hasil Seminar Hukum Nasional IV tanggal 26-30 Februari 1979 dikatakan bahwa, Pancasila yang mengandung nilai-nilai kejiwaan bangsa Indonesia merupakan dasar tertib hukum Indonesia, pedoman dan penunjuk arah perkembangannya dengan sistem yang terbuka dan adalah batu ujian mengenai kepatutan dan perundang-undangan. Dalam menyusun undang-undang, pembentuk undang-undang perlu dengan tepat menunjukkan nilai-nilai Pancasila, yang mendasari ketentuan undang-undang itu. Dengan demikian peraturan-peraturan hukum merupakan merupakan pelaksanaan undang-undang itu tidak boleh mengandung hal-hal yang bertentangan dengan Pancasila. Pencerminan nilai-nilai Pancasila di dalam perundang-undangan merupakan hakekat pembentukan sistem hukum nasional. ${ }^{15}$

Berdasarkan uraian tersebut diatas menunjukkan bahwa dalam membangun sebuah produk hukum perturan perundang-undangan (Perda) nilai-nilai kejiwaan bangsa Indonesia, nilai-nilai Pancasila harus termuat dalam ketentuan peraturan perundang-undangan (Perda). Maka dengan demikian pemahaman terhadap Pancasila secara komprehensif baik terhadap asas-asas yang dikandungnya, nilai-nilainya, dan cita hukum yang terkandung didalam Pancasila mutlak harus dipahami oleh institusi pembuat hukum atau lembaga yang berwenang membuat hukum, lembaga penerap sanksi, maupun oleh pemegang peran. Pemahaman yang komprehensif mengenai hal tersebut maka produk hukum berupa peraturan perundang-undangan (Perda) akan

13 Khudzaifah Dimyati, 2005, Teorisasi Hukum Studi Tentang Perkembangan Pemikiran Hukum Di Indonesia 1945-1990, Surakarta: Muhammadiyah University Press, hlm. 192.

14 Moh. Mahfud MD, 2010,Membangun Politik Hukum Menegakkan Konstitusi. Jakarta: PT. Raja Grafindo Persada, hlm. 55.

15 Barda Nawawi Arief, Op. Cit., hlm. 30-31. 
melahirkan produk hukum peraturan perundang-undangan berbasis cita hukum Pancasila, yang sudah barang tentu jauh dari nilai-nilai seperti dianut dalam budaya hukum barat yang berciri liberal-individualistik.

Membangun produk hukum berupa peraturan perundang-undangan (Perda) berbasis cita hukum Pancasila harus berpijak kepada kerangka pembangunan hukum/politik hukum, berparadigma Pancasila yakni: ketuhanan, kemanusiaan, persatuan, kerakyatan dan keadilan dengan bertumpu kepada kelima sila-sila dari Pancasila serta asas-asas umum dari hukum nasional yakni: asas manfaat, asas usaha bersama dan kekeluargaan, asas demokrasi, asas adil dan merata, asas perikehidupan dalam keseimbangan, asas kesadaran hukum, asas kepatutan, dan asas kerukunan serta asas keselarasan. Dan asas-asas yang terkandung di dalam Undang-Undang Dasar NKRI 1945.

\section{Konsep Ideal Dalam Membangun Produk Hukum Peraturan Daerah Pertambangan Mineral Dan Batubara Berbasis Cita Hukum Pancasila}

Membangun produk hukum berupa peraturan perundang-undangan (Perda) khususnya peraturan daerah pertambangan mineral dan batubara ada beberapa hal yang harus mendapat perhatian utama yakni: 1). Bahwa pertambangan mineral dan batubara adalah merupakan kekayaan alam Indonesia yang tidak terbarukan; dan merupakan karunia Tuhan Yang Maha Esa; 2). Bahwa pertambangan mineral dan batubara yang merupakan kekayaan alam Indonesia adalah merupakan kekayaan rakyat Indonesia; 3). Bahwa dalam pengelolaan pertambangan mineral dan batubara harus dapat mendatangkan kemanfaatan dan kemakmuran bagi rakyat Indonesia secara nyata; 4). Bahwa penguasaan negara terhadap sumber daya alam berupa pertambangan mineral dan batubara dalam pengertian pengaturan, pendistribusian dan pemanfaatannya tidak boleh dilakukan secara sewenang-wenang; 5). Bahwa pengusahaan pengelolaan pertambangan mineral dan batubara tidak boleh dikelola secara liberal-kapitalistik.

Kelima hal tersebut di atas dapat diwujudkan apabila instrumen hukum yang mengatur pengelolaan pertambangan mineral dan batubara didasarkan pada cita Hukum Pancasila yang untuk selanjutnya dijabarkan dalam Pasal 33 UUD NKRI 1945. Berangkat dari pemahaman terhadap makna Pasal 33 tersebut dalam membangun produk hukum peraturan daerah pertambangan mineral dan batubara seharusnya diarahkan kepada, pembangunan produk hukum peraturan daerah pengelolaan pertambangan mineral dan batubara guna meningkatkan kemakmuran dan kesejahteraan rakyat pada umumnya utamanya masyarakat lokal, karenanya produk hukum peraturan daerah pertambangan mineral dan batubara tidak boleh 
mengandung unsur liberal-kapitalistik, dimana pengelolaannya harus dilakukan sebagai usaha bersama berdasarkan asas kekelurgaan, asas kebersamaan dan asas kegotong-royongan dalam bentuk koperasi.

Pada sisi yang sama produk hukum peraturan daerah pertambangan mineral dan batubara harus mencerminkan nilai keadilan sosial, dimana dalam pengelolaannya tidak boleh merugikan kepentingan rakyat baik rakyat kedudukannya sebagai individu maupun kedudukannya sebagai anggota kelompok masyarakat. Dengan demikian membangun produk hukum berupa peraturan perundang-undangan termasuk peraturan daerah dalam berbagai bidang dengan mempergunakan paradigma Pancasila dan atau berbasis cita hukum Pancasila akan menghasilkan produk hukum yang sarat dengan nilai-nilai moral, ketuhanan, kemanusian, persatuan, kerakyatan dan keadilan sosial. Implikasinya hukum tidak bisa lagi dijadikan sebagai alat untuk melakukan penindasan, dan sebagai alat untuk melakukan eksploitasi.

\section{Simpulan}

Berdasarkan uraian yang telah dikemukakan di atas, maka dapat disimpulkan bahwa, dalam rangka membangun produk hukum peraturan daerah pertambangan mineral dan batubara yang sesuai dengan cita hukum Pancasila, maka paradigma yang harus dipergunakan adalah paradigma Pancasila. Yakni: Pertama, bahwa produk hukum peraturan daerah pertambangan mineral dan batubara harus memuat nilai-nilai moral Ketuhanan Yang Maha Esa, artinya dalam pengelolaan pertambangan mineral dan batubara yang merupakan kekayaan alam yang diberikan oleh Tuhan Yang Maha Esa kepada bangsa Indonesia dalam pengusahaan dan pengelolaannya harus mendatangkan manfaat serta kemakmuran dan kesejahteraan bagi seluruh rakyat Indonesia.

Kedua, bahwa produk hukum pertambangan mineral dan batubara harus memuat nilai-nilai kemanusiaan, nilai-nilai keadilan dan nilai-nilai yang dapat mengangkat harkat dan martabat rakyat Indonesia, utamanya masyarakat lokal. Ketiga, bahwa produk hukum pertambangan mineral dan batubara harus memuat nilai-nilai persatuan dan kesatuan masyarakat, hal ini dapat diartikan bahwa dalam pengusahaan pengelolaan pertambangan mineral dan batubara harus mengedepankan kebersamaan, kerukunan dan keselaraan, serta kegotong-royongan. Keempat, bahwa produk hukum pertambangan mineral dan batubara harus memuat nilai-nilai kerakyatan, artinya bahwa produk hukum peraturan daerah harus mengandung nilainilai demokrasi. Kelima, bahwa produk hukum peraturan daerah pertambangan mineral dan batubara harus mencerminkan nilai-nilai keadilan sosial. 


\section{Daftar Pustaka}

Attamimi A. Hamid S, dkk, 1991, Pancasila Sebagai Ideologi Dalam Berbagai Bidang Kehidupan Bermasyarakat, Berbangsa Dan Bernegara, Jakarta: BP-7 Pusat.

Arif Nawawi Barda, 2008, Kumpulan Hasil Seminar Nasional Ke I S/D VIII Dan Konvensi Hukum Nasional 2008, Semarang: Pustaka Magister.

Arinanto Satya dan Triyanti Ninuk, 2009, Memahami Hukum Dari Konstruksi Sampai Imlementasi, Jakarta: PT. Raja Grafindo Persada.

Anshori Ghofur Abdul, 2008, Menggali Makna Sistem Hukum Dalam Rangka Pembangunan Ilmu Hukum Dan Sistem Hukum Nasional, Orasi Ilmiah Dies Natalis Fakultas Hukum UGM, Ke-62, Yogyakarta: Fakultas Hukum UGM.

Dimyati Khudzaifah, 2005, Teorisasi Hukum Studi Tentang Perkembangan Pemikiran Hukum Di Indonesia 1945-1990, Surakarta: Muhammadiyah University Press.

Hidayat Arief, 2011, .Negara Hukum Pancasila (Suatu Model Ideal Penyelenggaraan negara Hukum), Makalah, Disampaikan Pada Semiloka Pendidikan Pancasila dan Konstitusi, Jakarta.

Kesowo Bambang, 2007, Aktualisasi Kultur Hukum Dalam Sistem Hukum Pancasila, Makalah, Disajikan Dalam Seminar Nasional, Yogyakarta: Fakultas Hukum dan KAGAMA.

Mahfud MD Moh, 2010, Membangun Politik Hukum Menegakkan Konstitusi,Jakarta: PT. Raja Grafindo Persada. ,2010, Konstitusi dan Hukum dalam Kontroversi Isu, Jakarta: PT. Raja Grafindo Persada.

Sidharta Bernard Arief, 1996, Refleksi Tentang Fundasi dan Sifat Keilmuan Ilmu Hukum Sebagai Landasan Pengembangan Ilmu Hukum Nasional Indonesia, (Disertasi), Universitas Padjadjaran, Bandung.

Soehino, 2006, Hukum Tata Negara Teknik Perundang-Undangan (Setelah Dilakukan Perubahan Pertama Dan Perubahan Kedua Undang-Undang Dasar Negara Republik Indonesia Tahun 1945), Yogyakarta: BPFE.

Thaib Dahlan, 2009, Ketatanegaraan Indonesia Perspektif Konstitusional, Yogyakarta: Total Media. 